Janaki Ammal, Chromosome atlas of cultivated plants. George Allen \& Unwin Ltd., London.

KeCK, D. D. 1959. Rigiopappus, p. 1152. In P. A. Munz, A California flora. University of California Press, Berkeley, Calif.

Raven, P. H., O. T. Solbric, D. W. Kyhos, and R. Snow. 1960. Chromosome numbers in Compositae. I. Astereae. Amer. Jour. Bot. 47: 124-132.

Rydreng, P. A. 1914. Carduaceae. Helenieae and Tagetinae. North Amer. Flora 34: 1-216.

Schnack, B., AND G. Covas. 1947. Estudios cariologicos en antófitas. Haumania 1 : 32-4I.

Shimokoriyama, M., and T. A. Geissman, 1960. Anthochlor pigments. XIV. The pigments of Viguiera multiflora (Nutt.) and Baeria chrysostoma (F. \& M.). Jour. Organ. Chem. 25: 1956-1959.

Shinners, L. H. 1959. Species of Laphamia transferred to Perityle (Compositae. Helenieae). Southw. Nat. 4: 204206.

Speese, Bernice M., and J. T. Baldwin, Jr. 1952. Chromosomes of Hymenoxys. Amer. Jour. Bot. 39: 685-688.

Stockwell, P. 1940. A revision of the genus Chaenactis. Contr. Dudley Herb. 3: 89-168.
Stovtamire, W. P. 1958. Cytological variation in Texas Gaillardias. Brittonia 10: 97-102.

Towner, J. W. 1958. Amphiploidy in the cultivated marigolds (Tagetes). Proc. X Int. Cong. Genet, 2: 296.

Turner, B. L. 1956. A cytotaxomonic study of the genus Hymenopappus (Compositae). Rhodora 58: 163-186, 208-242, 250-269, 295-308.

- 1959. Meiotic chromosome counts for 12 species of Texas Compositae. Britonnia 11: 173-177.

_- J. M. Beaman, and H. F. Rock. 1961. Chromosome numbers in the Compositae. V. Rhodora (in press).

_- AND W. L. Ellison. 1960. Chromosome numbers in the Compositae. I. Meiotic chromosome counts for 25 species of Texas Compositae including 6 new generic reports. Texas Jour. Sci. 12: 146-151.

$\longrightarrow$ - $\longrightarrow$ AND R. M. Kinc. 1961. Chromosome num. bers in the Compositae. IV. North American species, with phyletic interpretations. Amer. Jour. Bot. 48: 216-223.

, And M. C. Johnston. 1961. Chromosome numbers in the Compositae. III. Certain Mexican species. Brittonia 13: 64-69.

\title{
OBSERVATIONS ON CHYTRIDIACEOUS PARASITES OF PHANEROGAMS. XI. A PHYSODERMA ON AGROPYRON REPENS ${ }^{1,2}$
}

\author{
F. K. Sparrow, Joyce E. Griffin and R. M. Johns \\ Department of Botany, University of Michigan, Ann Arbor, Michigan \\ and \\ Department of Botany, Indiana University, Bloomington, Indiana
}

\begin{abstract}
A B S T R A C T
Sparrow, Frederick K. (U. Michigan, Ann Arbor), Joyce E. Griffin, and Robert M. Johns. Observations on chytridiaceous parasites of phanerogams. XI. A Physoderma on Agropyron repens. Amer. Jour. Bot. 48(9) : 850-858. Illus. 1961.-A Physoderma has been found in Michigan on Agropyron repens, which produces dark-brown, non-erumpent streaks up to $20 \mathrm{~mm}$ (usually 4-6 $\mathrm{mm}$ ) in length by $0.5 \mathrm{~mm}$ in width and very local discoloration of the leaf blades and sheaths. There is no systemic infection, and plants parasitized are norm $\mathrm{l}$ in size and bear flowers. Resting spores upon germination produce zoospores which may develop either into the endobiotic, polycentric, resting spore-bearing thallus or into monocentric, epibiotic, ephemeral sporangia. The latter bear either colorless or orange globuled zoospores. These zoospores may give rise to new epibiotic sporangia, or, apparently without fusing in pairs, to the endobiotic system. Comparison with other congeneric fungi reported on Agropyron repens reveals the Michigan fungus to be distinct from them. Whether it can be embraced within Physoderma graminis (Büsgen) de Wild. or other described taxa on grasses awaits the results of future cross-inoculation studies.
\end{abstract}

OF THE several species of Physoderma which have been found on grasses, that parasitizing Agropyron repens. (L.) Beauv. has been commonly ascribed to $P$. graminis (Püsgen) De Wild. Whether one can agree with the various observers of "P. graminis," including those reporting it from Agropyron repens, that they were all, in fact, dealing with the same species seems open to question.

The species name "graminis" was first applied by

1 Received for publication April 20, 1961.

Contribution No. 1128, Botany Department; Biological Station, University of Michigan.

2 Acknowledgement is made to the National Science Foundation for support of this work.
Büsgen (1887) to a fungus considered by him to be a species of Cladochytrium. The material was given him by De Bary with whom he was evidently working at the time at Strasbourg University, then a German institution. It consisted of a glycerine preparation of an unknown grass collected over $20 \mathrm{yr}$ earlier. Resting spores $40 \mu$ long $\times 30 \mu$ wide were found in the "Rindenparenchyms" of a grass root. In addition to these, De Bary had also noted delicate threads with swellings resembling the turbinate organs of Physoderma lutomi which Büsgen was currently studying. The species was later placed in Physoderma by De Wildeman (1896) in a routine nomenclatorial change. Since a search for 
the type material of $P$. graminis both in the De Bary collection at the British Museum (N.H.) and at the University of Strasbourg ${ }^{3}$ has proven fruitless, it is not known precisely what De Bary had or on what host his fungus occurred. Furthermore, since there were no illustrations, it can be seen that the species rests upon a very tenuous basis, indeed.

With the issuance of Krieger's "Fungi saxonici" (1888), there appeared on the packet label a somewhat expanded description of "Cladochytrium graminis" on a grass, which, because of the systemic infection by the fungus, was stunted, unable to bloom, and hence, unidentifiable. Yellow-brown parallel stripes caused by the fungus were on the leaves, but there was no mention that the roots were infected. Within the leaves were brown, globose or somewhat elliptical resting spores, 27$45 \mu$ long $\times 20-30 \mu$ wide. A study of Krieger's material (Fungi saxonici \#441) indicates clearly that he was dealing with a species of Physoderma. That it was identical with De Bary's material on which Büsgen based his species does not now seem susceptible of proof.

It is not our intention at this time to discuss in a comparative fashion all the species of Physoderma (including Cladochytrium) which have been described from grasses ( $P$. gerhardti, $P$. agrostidis, $P$. maydis, $P$. paspali, $P$. echinochloae, etc.) but, rather, to turn attention to one which has recently been found in the vicinity of the University of Michigan Biological Station at Douglas Lake by R. M. Johns on Agropyron repens. There was unmistakable evidence even in mid-June that the site on which infected plants stood (a roadside) had been flooded earlier in the growing season, a fact confirmed by a local resident.

Infection was non-systemic; there was no stunting, and the plants grew to full maturity and flowered. The Physoderma was present only on the blades and sheaths of the leaves and on the scales at the base of the erect part of the plant. In these areas it produced dark-brown, non-erumpent streaks from less than a millimeter to $20 \mathrm{~mm}$ in length and up to $0.5 \mathrm{~mm}$ in width, the commonest length being 4-6 $\mathrm{mm}$. Such streaks occurred singly on the leaf or were so frequent as completely to speckle that structure.

MATERIALS AND METHODS-Infected material, primarily dead, brown leaves, was placed in plastic bags and immediately stored after collection in a Deepfreeze. It was maintained in a frozen condition for $4 \mathrm{mo}$, at which time small amounts were removed and tests for germination of the resting spores were initiated. Precisely how soon after collection spores were capable of germination was not determined; it is known that they did so after the aforementioned time interval. Infected leaves were also pressed and dried after collection, and spores

3 Thanks are due Professor H. R. Maresquelle of the Botanical Institute, University of Strasbourg, and The Keeper of Botany, British Museum (N. H.) for their efforts in attempting to locate this material. from these, too, germinated, but in smaller numbers, after $4 \mathrm{mo}$.

Resting spores were scraped from host parts into shallow watch glasses of charcoal water and placed in glass damp chambers. The latter were for the most part placed at fluctuating room temperatures approximately 6-10 in. from a 15-W Mazda daylight lamp. Others were placed in a constanttemperature $(23 \mathrm{C})$ and -light room. In both places similarly prepared, aluminum-foil-covered dishes were also set up. Germination to zoospore production took place under all conditions in $41-48 \mathrm{hr}$. Dried, but not frozen, resting spores were somewhat slower in germinating.

In following the development of the epi- and endobiotic stages of the parasite, grass seedlings approximately $2 \mathrm{~cm}$ long were placed in watch glasses of water having germinating resting spores and their zoospores. The latter came to rest in great numbers on the seedlings, particularly on the nearly colorless coleoptiles, and developmental stages of the fungus could be followed with comparative ease. Seedlings of not only Agropyron repens but also of A. subsecundum ${ }^{4}$ and several other grasses were utilized.

GERMination OF THE RESTING SPORE-Germination of any population of resting spores was not simultaneous but successive, and once initiated the great majority of individuals germinated over a period of $48 \mathrm{hr}$. The mature resting spore prior to initiation of germination is ellipsoidal to somewhat irregular in outline (Fig. 1, 2), often flattened on one surface and 15-34 $\times 12-22 \mu$ (av. 21.5 $\times$ $16.6 \mu)$. Its wall is pale, amber-colored, approximately $2 \mu$ thick and in cleared specimens is seen to bear 2-4 pits scattered supraequatorially on its more convex face. The contents are disposed in the same highly characteristic manner as in all other species of the genus we have observed; namely, there is a large central vacuole of somewhat irregular outline, which stains with neutral red but not Sudan III, surrounded by 1-3 rows of globules which absorb the last-named dye and hence are presumed fatty in nature.

The first indication that germination has been initiated is the circumscissile dehiscence after $24-25$ hr of a $15-20 \mu$ broad lid from the more flattened face of the spore (Fig. 3). This lid is gradually forced away from its concomitant spore wall by the slow elongation and consequent protrusion of a thin-walled part of the endosporangium beneath it. Sometimes separation of the lid is complete, and it is carried upwards, whereas in other instances it may remain partially attached and be merely pushed aside. At the stage of cap dehiscence, the large, central, neutral red-absorbing vacuole and its surrounding globules are intact and unchanged. In the ensuing 3-4 hr, however, the globules become markedly uneven in size, some being larger, some

4 We are indebted to Dr. Kent McKnight of Brigham Young University for seeds of this and other species. 

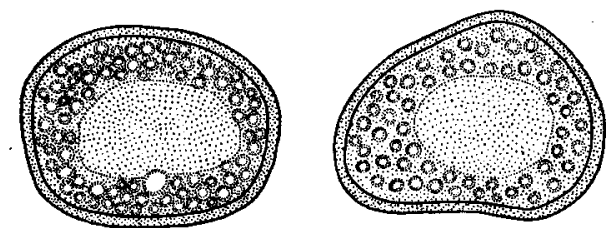

2
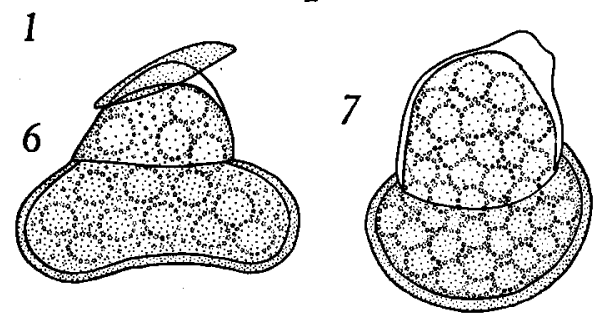

${ }_{11}^{0}{ }_{12}{ }_{13} 8$

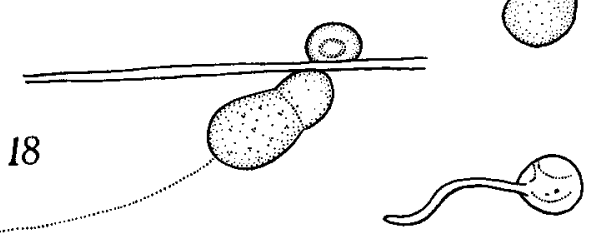

19

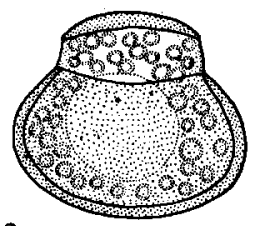

3
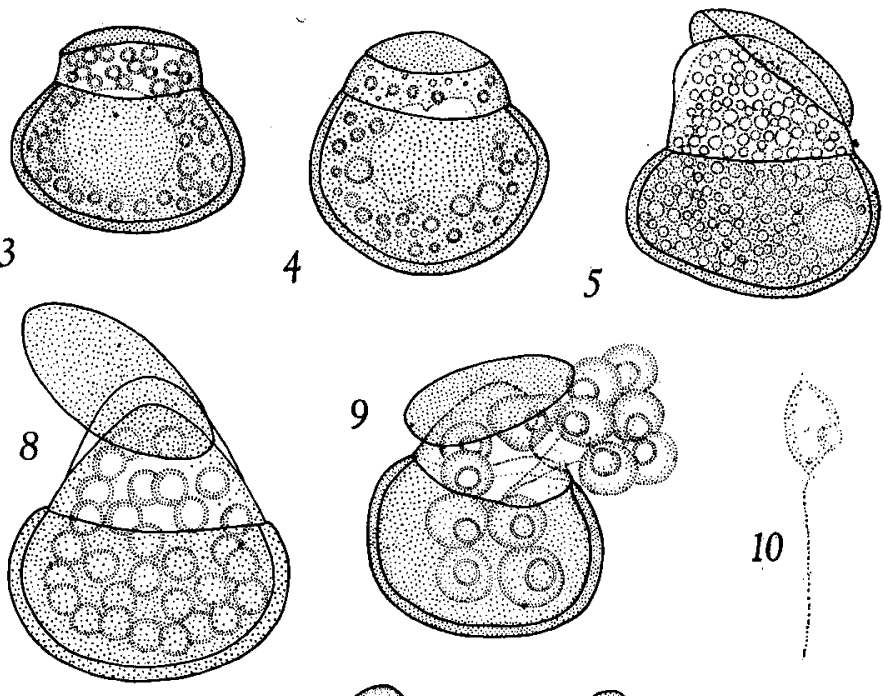

5

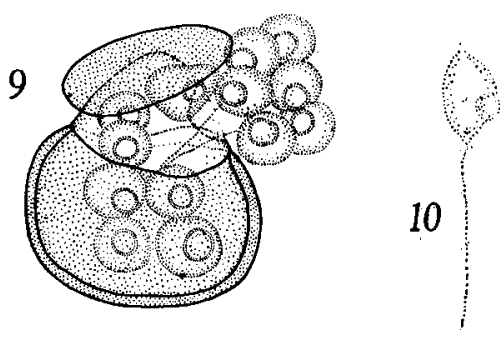

15

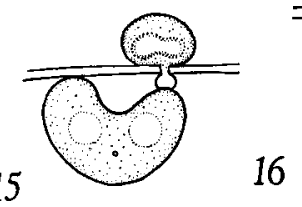

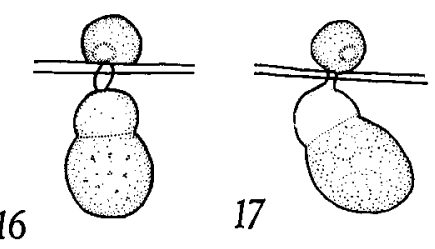

b
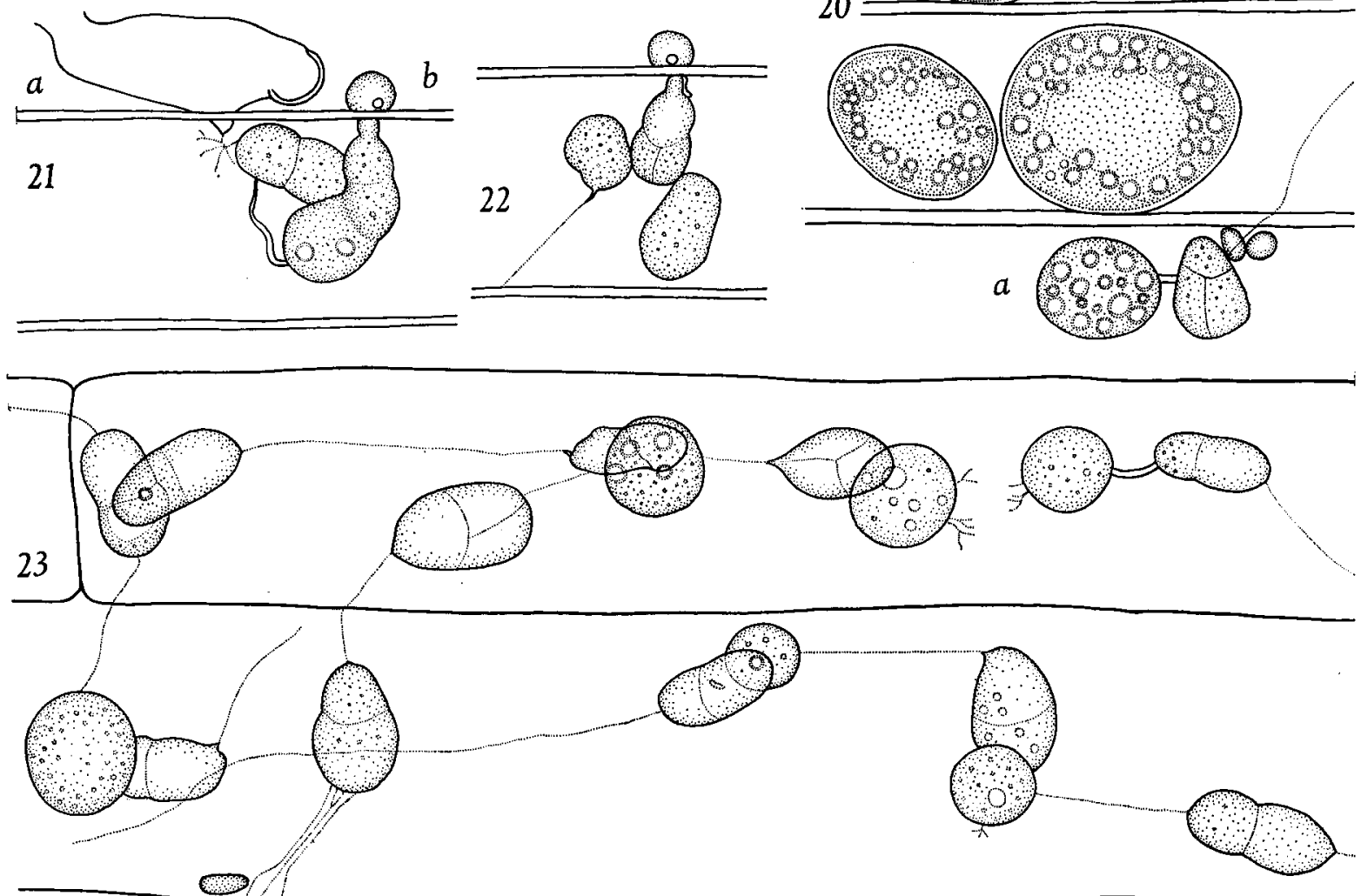
smaller than their precursors (Fig. 4). Approximately $10 \mathrm{hr}$ after initiation of cap dehiscence, the central vacuole begins to disappear, and the by now broadly conical protuding apex of the endosporangium forms a prominent apical papilla which strongly absorbs neutral red. The contents of the endosporangium are now very unevenly granular and contain numerous large and small refractive bodies (Fig. 5) some material of which may possibly have been derived from the vacuole. In a few hours this stage is superseded by a distinctly more homogeneously granular one as the refractive bodies break down. The resultant like-sized granulations appear successively to become organized into what we term the "ring stage" (Fig. 6). This stage is a striking one by reason of the formation in the contents of hollow spheres of highly refractive beadlike globules. These are equally spaced and approximately $3 \mu$ in diameter when fully formed; that is, essentially the same size as the globule of the mature zoospore. As a result of continued ring formation, granulation of the endosporangium contents gradually disappears (Fig. 7) and the areas bounded by the rings become highly refractive. It seems that both the material of the rings and the refractive granulations of the now clear contents have combined to form the globules of the future zoospores (Fig. 8). Thus the rings seem to function as centers of condensation of materials which make up the zoospore globules. Stages in the segmentation of the contents to form mature zoospores are not visible save in stained sections. The endosporangium when fully mature has a broadly conical external portion, $13-15 \mu$ long $\times 12-15 \mu$ wide at the base tapering to 6-7 $\mu$ apically, and an internal part within the resting spore wall (Fig. 8). Approximately 16-48 zoospores are produced, as indicated by the number of globules in the contents.

Zoospore discharge, which occurs $41-48 \mathrm{hr}$ after original immersion of the resting spores, takes place by the sudden swelling and subsequent quick deliquescence of the apical papilla. The first swarmers, surrounded by the rapidly expanding material of the papilla, are passively ejected en masse through a broad discharge pore. After a few moments, how- ever, during which time the "slime" becomes dissolved into the water, the swarmers initiate individual flagellar movement and swim away followed by the now actively motile remainder within the endosporangium (Fig. 9). The zoospores are at first spherical and approximately $7 \mu$ in diameter but assume a somewhat fusiform shape when in motion. They are calculated to be $10-12 \mu$ long by $5-6 \mu$ broad and bear eccentrically a protruding, colorless, globule 3-4 $\mu$ in diameter (Fig. 10). The latter turns deep-orange-brown with Sudan III. Within the body are borne apically a few minute globules and laterally several vacuoles. At the point of attachment of the $30-\mu$ long posterior flagellum, a refractive blepharoplast may usually be seen, but the nuclear cap which is conspicuous in stained prepara. tions is ordinarily invisible in the living spore.

Development from the Resting Spore ZooSPORES-Precisely how long the zoospores remain motile before coming to rest on the host plant or free in the water is not known. Twenty-four hr after placing the seedlings in the dish with the zoospores, great numbers could be found encysted on the host plant. Others lay free in the water and often formed well-developed unbranched or branched germ tubes up to $15 \mu$ in length (Fig. 19). The cysts of the quiescent zoospores, which were 5-6 $\mu$ in diameter, were observed to form primarily on the coleoptile, less often on the first leaf. In our material, a rather remarkable and certainly unforeseen situation now ensued, namely, the sporeling very clearly could undergo 1 of 2 pathways of development. One resulted in the formation of the extensive endobiotic, polycentric system which ultimately produces the resting spores; the other in the production of the monocentric epibiotic, "ephemeral" sporangial stage. That swarmers from resting spores may develop in either of these 2 fashions has been confirmed by a series of observations under conditions and time schedules which rule out any other conclusion. Just what controls the pathway each spore will take in its development is under investigation at the moment. For example, possible fusions of resting spore zoospores have been watched for but not found in living material.

Fig. 1-23.-Fig. 1, 2. Two resting spores before initiation of germination.-Fig. 3. Early stage in germination, showing circumscissile dehiscence of cap and beginning of emergence of endosporangium.-Fig. 4, 5. Later stages showing unequal-sized globules and in Fig. 5, beginning of formationof discharge papilla.-Fig. 6. Appearance of "ring stage" in granular contents.-Fig. 7. Continued ring formation with clearing of contents.-Fig. 8. Globules of zoospores in mature endosporangium.-Fig. 9. Discharge of zoospores.-Fig. 10. Single resting spore zoospore showing shape while in motion (freehand).-Fig. 11., 12. Young stages in establishment of endobiotic system; the cyst of the infecting zoospore uppermost.-Fig. 13-15. Establishment of primary turbinate organ in host.-Fig. 16, 17. Septation of primary turbinate organ.Fig. 18. Establishment of first rhizoid.-Fig. 19. Stained resting spore zoospores lying free in water with long germ tubes.-Fig. 20. Stages in formation of resting spores in seedling 8 days after inoculation with resting spore zoospores; (a) young resting spore formed at tip of a lateral outgrowth from a 3-celled turbinate organ; (b) at right another young spore produced as lateral outgrowth from turbinate organ, the former bearing a cluster of haustorial appendages. To left and below are nearly mature resting spores.-Fig. 21. Portion of a host cell 4 days after exposure to zoospores from epibiotic sporangia; (a) empty epibiotic sporangium; (b) zoospore cyst to which is attached primary turbinate cell with rhizoid; other septate cell possibly from another infection.-Fig. 22. Portion of host cell $48 \mathrm{hr}$ after exposure to zoospores from epibiotic sporangia, showing primary turbinate organ already septate; other turbinate cells may be from other infections.-Fig. 23. Several cells of host with thallus of parasite ramifying through them. Resting, spores in various stages of development, some bearing haustoria, are shown. All figures $\times 990$. 

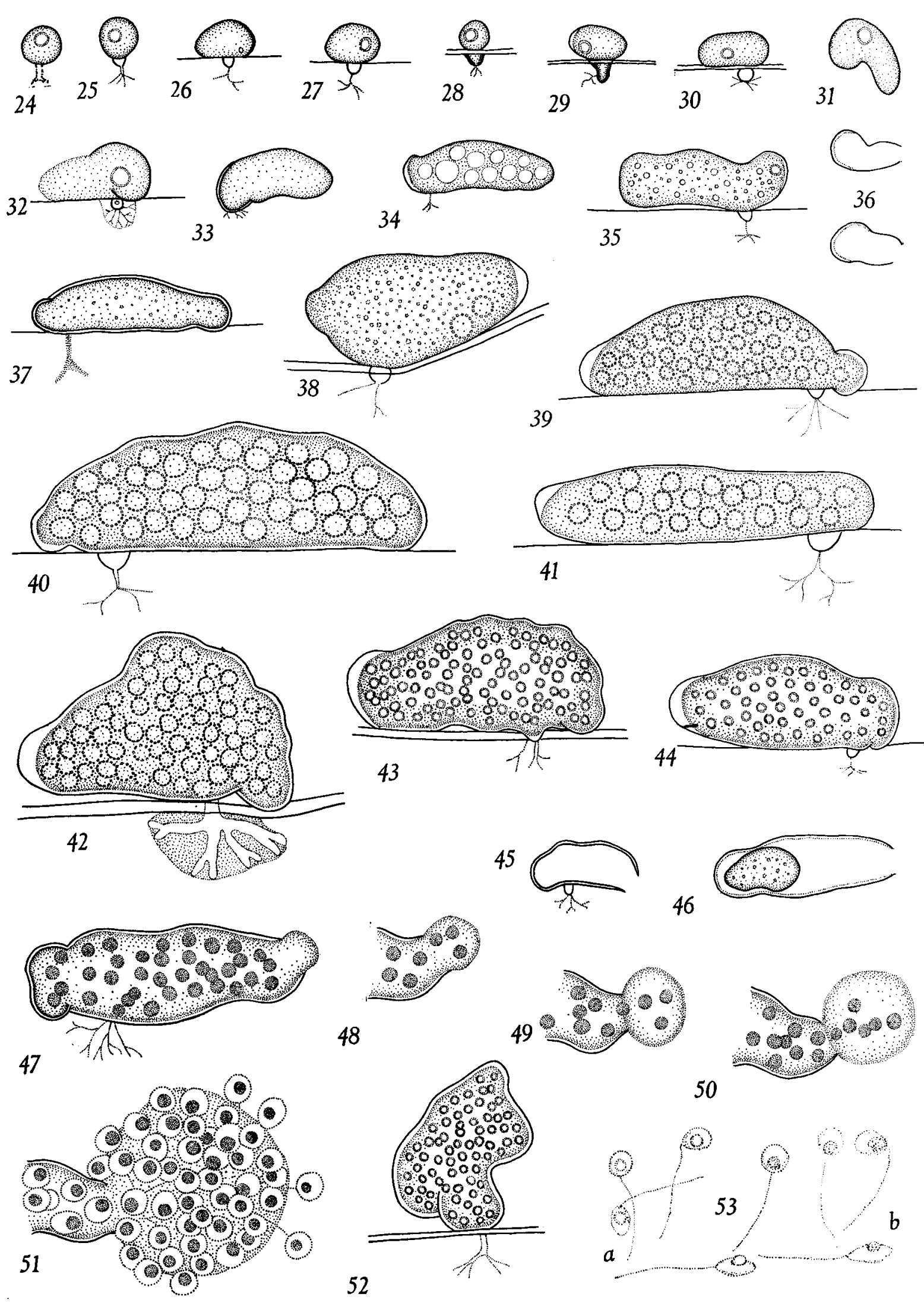
ENDoBiotic STAGE-Establishment and development of the endobiotic thallus is as follows. In the earliest stages observed, the contents of the zoospore cyst, save for the globule, move through a delicate tube into the host cell on the inner face of which they form an apparently naked mass of protoplasm, approximately $6 \mu$ in diameter. This soon rounds off (Fig. 11, 12) and later becomes elongate (Fig. 13), asymmetrically pyriform and sometimes curved (Fig. 14, 15). When this structure, which may be considered the primary turbinate organ, becomes approximately $12 \mu$ long $\times$ $5-8 \mu$ in diameter, it is frequently divided by a cross wall into 2 unequal portions (Fig. 16). If certain refractive bodies in the otherwise homogeneous protoplasm are, as suspected, nuclei, the turbinate organ before septation is multinucleate. During establishment of the turbinate organ, the globule in the epibiotic cyst decreases little, if at all, in size. Frequently, the upper, smaller segment of the turbinate organ soon loses its contents to the larger distal one (Fig. 17). There is then produced from the base of the latter a delicate process which steadily elongates and lays down the rudiments of the polycentric rhizoidal system on which further turbinate organs are formed (Fig. 18, 23). The delicate rhizoids wander from cell to cell and form more turbinate organs. As early as $72-76 \mathrm{hr}$ after original immersion of the seedling, rudiments of the resting spores are formed (Fig. 23). The turbinate organs are subcylindrical with rounded ends, $5-7.5 \times$ $12-14 \mu$ and usually have a single transverse septation which slightly constricts them, or occasionally a vertical one as well (Fig. 20, 23); more ovate, 2-3-celled ones, $3-12 \mu$ wide $\times 13-15 \mu$ long are also fairly numerous.

As seen in Fig. 20, 23, the resting spore is formed at the tip of a very short delicate tube which emerges laterally from the more distal cell of the turbinate organ. Such a lateral origin for the resting spore has been found to be the predominant method in all species of Physoderma (as opposed to Urophlyctis) observed by us and is well shown in the figures of Büsgen (1887) and Clinton (1902) in the cases of $P$. butomi and $P$. maculare (the type of the genus), respectively. When the developing resting spore is approximately $10 \times 8 \mu$, one or several delicate, antler-like haustorial processes are formed on the face farthest from the point of attachment to the tube. In this particular fungus there are seldom more than 4-2 and 3 being the usual number (Fig. 23). The contents of the developing resting spore at this time are finely granular and shot through with bright globules of varying size. As enlargement continues there is also an increase not only in the size of the refractive inclusions but of their number as well, and, as a consequence, a coarsely granular aspect is now imparted to the contents (Fig. 20a). When the developing resting structure reaches a breadth of approximately $20 \mu$, a thickening and pigmenting of its wall is initiated (Fig. 20b). Coincident with these changes there is a reorganization of the contents. The refractive, irregularly shaped inclusions begin to assume a more peripheral position in the spore rudiment and become smaller and more like-sized (Fig. 20, middle). It is now evident that there is a central vacuole forming around which the fatty inclusions are becoming oriented. As wall thickening continues the inclusions become steadily more alike in size until at full maturity the resting spore exhibits the typical organization of the contents previously described.

It should be emphasized that resting-spore formation on a particular thallus is a successive, not a simultaneous, process, and all stages may be found within a limited area of invaded host tissue as early as $\mathbf{8}$ days after original exposure of the grass to the fungus zoospores. The great majority of resting spores lie free in the host cells, often in long files; a few may assume the shape of a small host cell in which they form. The aforementioned pits on the mature resting-spore wall no doubt mark the places where the now dehisced antler-like haustoria emerged from the spore rudiment.

EPIBIOTIC STAGE-The second pathway of development of the resting spore zoospore leads to the production of so-called "ephemeral" or "epiobiotic" sporangia. These are produced for the most part on the coleoptile, although later-formed ones may be found on the first leaf

In the formation of epibiotic sporangia, the encysted zoospore penetrates the wall of the host cell, but, rather than discharging its contents into

Fig. 24-53.-Fig. 24. Very early stage in formation of epibiotic sporangium. Zoospore has encysted, produced a penetration tube within host cell which has started to branch.-Fig. 25. Apophysis has formed by secondary swelling of portion of germ tube.-Fig. 26, 27. Beginning of unilateral elongation of spore body; in Fig. 26 a thickening of a portion of wall of cyst is visible.-Fig. 28, 29. Encysted spores with endobiotic system nearly engulfed by host wall material. -Fig. 30-33. Further stages in elongation of sporangial rudiment; in Fig. 33 the globule has finally disappeared.-Fig. 34. Temporary vacuolate stage.-Fig. 35. Contents bearing unequal-sized refractive inclusions. -Fig. 36. Two very small sporangia formed under crowded conditions which have discharged their contents.-Fig. 37. Stage following that shown in Fig. 35; contents now more evenly granular.-Fig. 38. Beginning of appearance of "ring stage".-Fig. 39-42. Sporangia in "ring stage" with granular contents. In Fig. 42 a peculiar webbing of rhizoids is seen.-Fig. 43, 44. Contents cleared and colorless globules of zoospores now formed.-Fig. 45. Empty sporangium.-Fig. 46. Internally proliferous sporangium.-Fig. 47. Fully mature epibiotic sporangium with orange globules.-Fig. 48-51. Stages in discharge of zoospores.-Fig. 52. Very irregularly shaped mature sporangium.-Fig. 53. Zoospores from epibiotic sporangia; (a) with colorless globules; (b) with orange globules. The 2 lower ones indicate fusiform shape while motile (freehand). All figures $\times 990$. 
the host, continues elongation of its penetration tube for a short distance and then produces distally a whorl of stubby, dichotomously branched rhizoids (Fig. 24, 25). Meanwhile, that portion of the tube nearest the inner surface of the host wall expands slightly and produces a small apophysis (Fig. 25). Twenty-24 $\mathrm{hr}$ after seedlings have been placed in water containing resting-spore zoospores, great numbers of encysted swarmers form a thin-walled, unilateral protrusion which often curves somewhat as it elongates (Fig. 30,31). As in other species of the genus a portion of the original cyst wall remains unexpanded and usually acts as a locus from which the rudiment of the thin-walled sporangium continues to grow (Fig. 26, 27). The host often attempts to prevent incursion of the fungus by wall formation around the developing rhizoidal system (Fig. $28,29)$. Wherever zoospores have encysted in great numbers in a limited area on the host, scant enlargement occurs and as early as $29 \mathrm{hr}$ after original immersion of the seedling, many empty, dwarf, epibiotic structures, some only $10 \mu \mathrm{long}$, can be found (Fig. 36). These could have given rise to 1 , or at the most, 2 zoospores. Under less crowded conditions, further growth of the epibiotic structure results in a somewhat elongate, sac-like clavate body whose long axis is parallel with the surface of the host cell (Fig. 32-35). This sporangium is usually gibbose (Fig. 42, 43) but occasionally may be strongly arched or highly irregular in shape (Fig. 52). In Fig. 42 a peculiar webbing of the rhizoids by host material is seen.

A feature of the Agropyron parasite was the fact that epibiotic sporangia of 2 types were produced, 1 with colorless hyaline inclusions in its contents and with colorless zoospore globule (Fig. 43, 44), the other with orange ones and with an orange globule in the zoospore (Fig. 47). This, it will be recalled, is the condition also found in Physoderma lycopi Sparrow (1957) and probably in P. maculare (Clinton, 1902) as well. The sequence of protoplasmic changes in both types is identical. When the lateral protrusion from the spore cyst is first initiated, the contents are finely granular and homogeneous save for the persistent globule of the zoospore (Fig. 24-32). During ensuing elongation of the sporangial rudiment this globule fragments and is evidently absorbed into the protoplasm. When sporangia have attained approximately half their mature size, vacuoles appear temporarily (Fig. 34), and are superseded by different-sized refractive inclusions (Fig. 35) which, as development proceeds, become more like-sized (Fig. 37). There then ensues the highly characteristic "ring stage" earlier noted in the development of the endosporangium of the resting spore (Fig. 38-42). These equidistant hollow spheres of globules are all of the same diameter in a particular sporangium and function to form the globules of the zoospores in the same manner as in the endosporangium. During these final stages in maturation a broad, blunt discharge papilla forms (Fig. 38-44).

Epibiotic sporangia vary greatly in size, probably depending upon the amount of food available to an individual in competition with others (Fig. 36, $42-43,45)$. The following are some random measurements: $55 \times 20 \mu ; 55 \times 10 \mu ; 18 \times 5 \mu$; $17 \times 7 \mu ; 65 \times 20 \mu ; 40 \times 12 \mu ; 35 \times 12 \mu$.

Discharge takes place upon the sudden swelling of the material of the papilla and the coincident passing out into it of the zoospores (Fig. 48-51). The latter are devoid of flagellar activity and, when nearly all have emerged, they form a large spherical mass at the sporangial orifice. Individual motility is soon initiated, the group falls apart and the zoospores swim away by their flagellar activity (Fig. 51 ). Although this is the typical behavior, in rare instances the spores are forcefully shot out of the sporangium, remain clumped for a few moments at some distance from the orifice and then swim away. They are spherical at first and $4-5 \mu$ in diameter but after becoming actively motile assume a fusiform shape and are 6-7 $\mu \times 4-5 \mu$. The colorless or orange globule is borne on the dorsal side of the body and strongly protrudes. Movement is an even one with frequent abrupt changes of direction accompanied by a constant slight rocking of the body from side to side.

BEHAVIOR OF THE ZOOSPORES FROM EPIBIOTIC SPORANGIA-A brief discussion is necessary at this point. In the life-history scheme proposed by the senior author (1940), it was suggested that planonts from epibiotic sporangia, in addition to forming new epibiotic sporangia (which by internal prolif. eration [Fig. 46] could form others), could also function as gametes. After these fused in pairs the resultant zygotes entered the host cells and gave rise to the endobiotic resting spore-bearing phase. Indeed, fusions of these zoospores have been reported by Sparrow (1957) in Physoderma ly. copi. In the closely related genus Urophlyctis, Y. Lingappa (1959) has not only described such fusions but the infection of the host by the zygote and establishment of the endobiotic system as well. In view of these findings and those reported earlier in this paper, namely, that resting-spore zoospores could form the endobiotic stage directly, it was important to learn if any product or structure of the epibiotic stage could do likewise.

Accordingly, seedlings of Agropyron bearing numerous epibiotic sporangia on their coleoptiles were thoroughly washed and microscopically examined to make certain that no ungerminated resting spores or motile resting-spore zoospores or zoospores of any kind were present. Some of these seedlings were then placed in new dishes and new seedlings added. Suitable controls were maintained. Under these conditions, any Physoderma infection of the new seedlings must have been accomplished by some element of the epibiotic stage. After $48 \mathrm{hr}$ in a constant-light and -temperature room (described 
Table 1. Comparison of 4 collections of Physoderma on Agropyron repens

\begin{tabular}{|c|c|c|c|c|}
\hline Collection & Host symptoms & $\begin{array}{l}\text { Resting spores } \\
\text { and zoospores }\end{array}$ & Turbinate cells & $\begin{array}{l}\text { Epibiotic } \\
\text { sporangia }\end{array}$ \\
\hline $\begin{array}{l}\text { Gopalkrishnan } \\
\text { (1951) }\end{array}$ & $\begin{array}{l}\text { Shortened internodes; leaves yellowing, } \\
\text { embryonically infected leaves hyper- } \\
\text { trophied, infected older ones longer than } \\
\text { uninfected; leaves with yellow striae } \\
\text { becoming brown; infection systemic, } \\
\text { including root and rhizome; basal rot- } \\
\text { ting; plant wilting. }\end{array}$ & $\begin{array}{l}20-40 \times 20-34 \mu ; \\
\text { wall orange- } \\
\text { brown, } 1-1.5 \mu \\
\text { thick; r. sp. zoo- } \\
\text { spores 2.5-6.5 } \times \\
2-4 \mu\end{array}$ & 2-3-celled & Present (?) \\
\hline $\begin{array}{l}\text { Thirumalachar and } \\
\text { Dickson (1947) }\end{array}$ & $\begin{array}{l}\text { Reduced internodes; leaves light-green } \\
\text { when young, older with pale yellow to } \\
\text { rusty-brown stripes; sori non-erumpent; } \\
\text { basal rotting. }\end{array}$ & $\begin{array}{l}20-40 \times 20-34 \mu \\
\text { wall reddish- } \\
\text { brown }\end{array}$ & & \\
\hline Childers (1948) & $\begin{array}{l}\text { Stunted host plants; leaves with brown } \\
\text { confluent streaks of considerable length. }\end{array}$ & $\begin{array}{l}23-33 \times 15-27 \mu^{\mathrm{n}} \\
(\text { av. } 27.1 \times 23 \mu)\end{array}$ & & \\
\hline $\begin{array}{l}\text { Sparrow, Griffin } \\
\text { and Johns }\end{array}$ & $\begin{array}{l}\text { No stunting; infection not systemic; } \\
\text { blades and sheaths of leaves with } \\
\text { brownish-black, elongate spots up to } \\
2 \mathrm{~mm} \text { in length; leaves discolored locally } \\
\text { around spots; inflorescence developed; } \\
\text { no basal rotting. }\end{array}$ & $\begin{array}{l}15-34 \times 12-22 \mu \\
(\text { av. } 21.5 \times 16 \mu) \\
\text { wall pale amber- } \\
\text { brown, } 2 \mu \text { thick; } \\
\text { r. sp. zoospores } \\
10-12 \times 5-6 \mu \text {. }\end{array}$ & $\begin{array}{l}\text { 2-3-celled; sub- } \\
\text { cylindrical with } \\
\text { rounded ends; } \\
12-14 \times 5-7.5 \mu\end{array}$ & $\begin{array}{l}\text { Elongate, saccate, } \\
\text { gibbose, pro- } \\
\text { cumbent with } \\
\text { cyst; variable in } \\
\text { size } 17-65 \times 5- \\
20 \mu \text {; zoospores } 5 \mu \\
\text { dia., with color- } \\
\text { less or orange } \\
\text { globule. }\end{array}$ \\
\hline
\end{tabular}

Our measurements.

earlier), as was expected, there were many unpigmented and pigmented epibiotic sporangia on the new seedlings. In addition, however, there were many unexpanded epibiotic zoospore cysts $5 \mu$ in diameter. These were unquestionably initiating development of the endobiotic system (Fig. 22) and in another $24 \mathrm{hr}$ had produced not only primary but secondary turbinate organs (Fig. 21). From these observations, and considering the short interval involved during which the endobiotic system was established, it appeared to us either that epibiotic zoospores were individually capable of producing the endobiotic system or that they were fusing, and, as suggested, the zygotes were functioning in this manner. The remainder of the aforementioned, washed seedlings with epibiotic sporangia had been set aside specifically for testing this last possibility. Their coleoptiles were excised and placed in Van Tieghem cells and their epibiotic sporangia allowed to discharge their zoospores. Very shortly, great numbers of swarmers were liberated and their behavior watched for some hours. Occasional pairing of swarmers were seen as well as some clumping but not with any significant frequency. The mounts were eventually killed and fixed with osmic acid and stained with gentian violet according to Cotner's method (1930). The permanent preparations were studied for evidences of fusions and, again, nothing convincing was found. We are not satisfied, however, that fusions never occur and are at present devising means of pursuing this important aspect further.

IDENTITY OF THE PARASITE-For reasons stated earlier, we do not feel our fungus can be referred to Physoderma graminis (Büsgen) De Wild., to which species other members of the genus on Agropyron have been assigned. Furthermore, pending a comprehensive study of species of Physoderma on grasses and of the results of extensive crossinoculation work, we will not attempt to place our fungus in any presently named taxon at this time. A comparison with other congeneric forms reported on Agropyron repens does seem pertinent, however, and data concerning these are presented in Table 1. It may be seen that the first 3 fungi are undoubtedly alike both in the symptoms they cause and in the size of their resting spores. Our fungus is distinct from these in not causing stunting or other evidence of systemic infection, in not producing basal rotting of the host plant and in not suppressing flowering. The resting spores are smaller and are found in brownish-black, elongate, non-erumpent spots, resembling in these respects $P$. gerhardti Schroeter. Other differences exist which, together with those enumerated, convince us that we are dealing with an entity distinct from others which have been described on Agropyron repens.

\section{LITERATURE CITED}

BüSGEN, M. 1887. Beitrag zur Kenntnis der Cladochytrien. In Cohn, Beitr. Biol. Pflanzen 4: 269-283.

Childers, W. R. 1948. Record of the occurrence of Physoderma graminis in Canada. Science 108: 484.

Cutnton, G. P. 1902. Cladochytrium alismatis. Bot. Gaz. 33: 49-61.

Cotner, F. B. 1930. Cytological study of the zoospores of Blastocladia. Bot. Gaz. 89: 295-309.

De Wildeman, E. 1896. Census Chytridinaearum. Bull. Soc. Roy. Bot. Belg. (Mém.) 35: 7-69.

Gopal.krishnan, K. S. 1951. Development and parasitism of Physoderma graminis (Büs.) Fischer, on Agropyron 
repens (L.) Beauv. Phytopath. 41: 1065-1076.

Krieger, W. 1888. Fungi saxonici. 441. Cladochytrium graminis Büsgen.

Lincappa, T. 1959. Sexuality in Physoderma pulposum Wallroth. Mycologia 51: 151-158.

Sparrow, F. K. 1940. Chytridiaceous fungi in relation to disease in flowering plants, with special reference to Physoderma, p. 514-516. In M. H. Dawson, [ed.],
Report of Proceedings, Third Internat. Congress for Microbiology, New York. viii +883 p.

- 1957. Observations on chytridiaceous parasites of phanerograms VII. A Physoderma on Lycopus americanus. Amer. Jour. Bot. 44: 661-665.

Thirumalachar, M. J., and J. G. Dickson. 1947. A Physoderma disease of quack grass. Phytopath. 37: 885-888.

\section{TRIARCH Ineorporated}

TRIARCH microscope slides have been a standard of quality for the past 34 years. Accept no substitutes. For free illustrated catalog listing slides for botany and zoology write to:

\section{TRIARCH Incorporated}

\section{GEO. H. CONANT}

